\title{
THE ACTION OF LEAD, MERCURY, PHOSPHORUS, IRON, AND QUININE ON THE BONE MARROW OF RABBITS. ${ }^{1}$
}

\author{
By Ralph Stockman, M.D., and Francis J. Charteris, M.B., \\ University of Glasgow.
}

(Plates XIV.-XVI.)

THE bone marrow in man and other mammalia undergoes very definite changes in many infective and wasting diseases, and under the influence of blood loss and poisons. These can be roughly described as consisting in an increase either (1) of its leucoblastic, or (2) erythroblastic cells, or (3) in gelatinous degeneration with diminution in the total number of its cellular elements.

Atrophy of the marrow fat and capillary hyperæmia often accompany and precede these changes, which occur very readily. The importance of this lies in the fact that the marrow is the great producer of the phagocytic leucocytes and of the red blood corpuscles. Its structure and functions are essentially the same in man and in other mammalia, such as the rabbit, guinea-pig, and dog, and the changes which it undergoes in disease, or under the action of poisons, are also similar. Hence we hoped, by making observations regarding the action of lead, mercury, phosphorus, and iron, on the bone marrow of rabbits, that some light might be thrown on their action on the bone marrow and blood in man. These substances were given by the mouth and hypodermically. In administering them subcutaneously we took care to avoid the occurrence of suppuration, which of itself markedly alters the marrow.

\section{LEAD.}

In chronic lead-poisoning in man anæmia is an early and marked symptom. Sometimes it is very severe, but commonly the red corpuscles number from 2 to 4 millions per c.mm., while the hæmoglobin decreases to 40 or 50 per cent. of the normal.

In one case Malassez (1) records 1,960,000 corpuscles and 19 per cent. hæmoglobin. In rabbits the same thing happens. In one, to which we gave 5 grs. of lead carbonate daily, mixed with its food, the corpuscles and hæmo-

1 Towards the expenses of this research a grant was made by the Government Grant Committee of the Royal Society. 


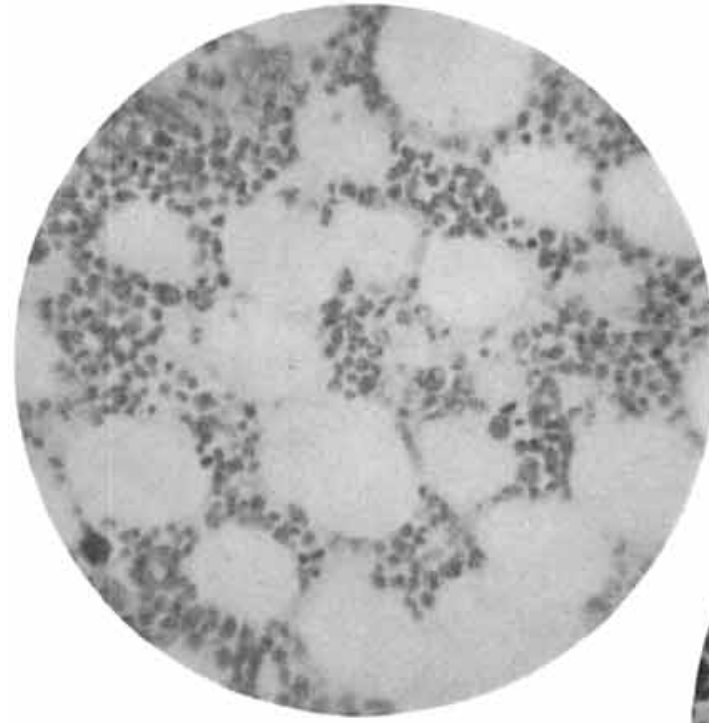

FIG, 1.

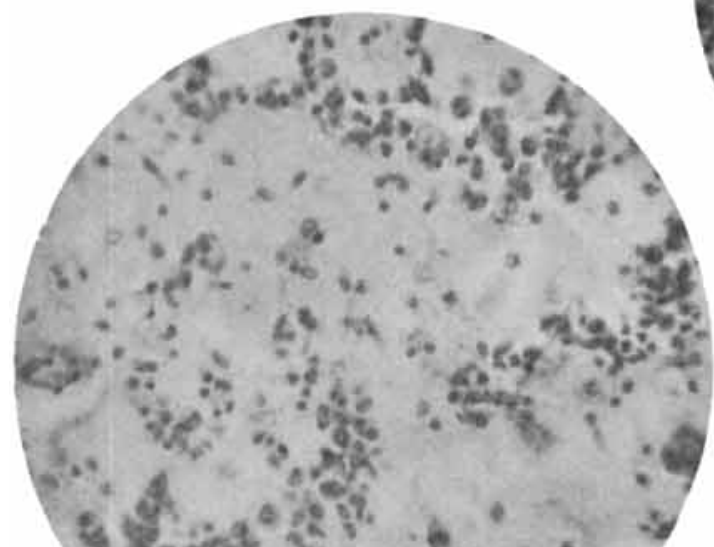

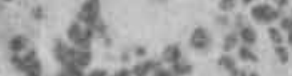

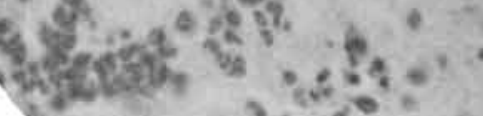

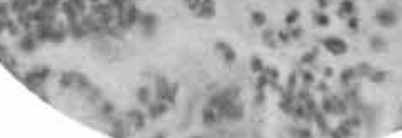

Fi6. 3.

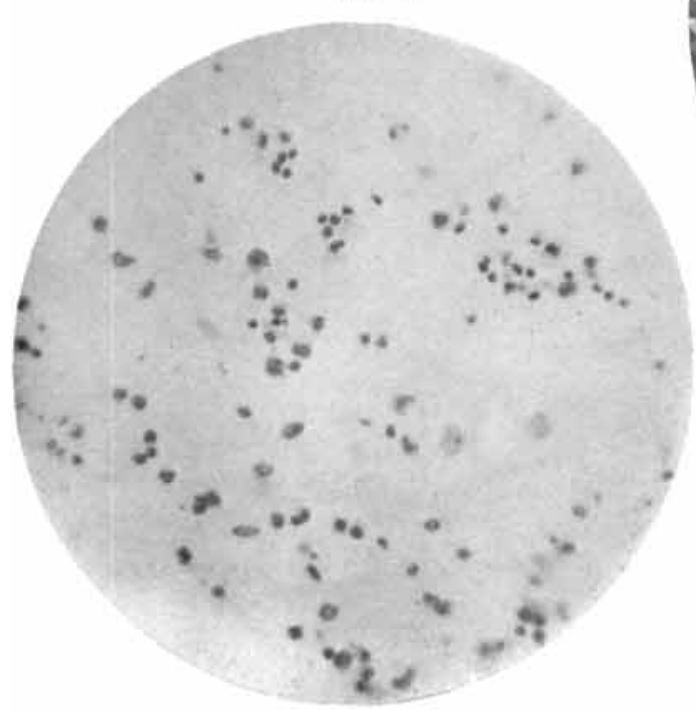

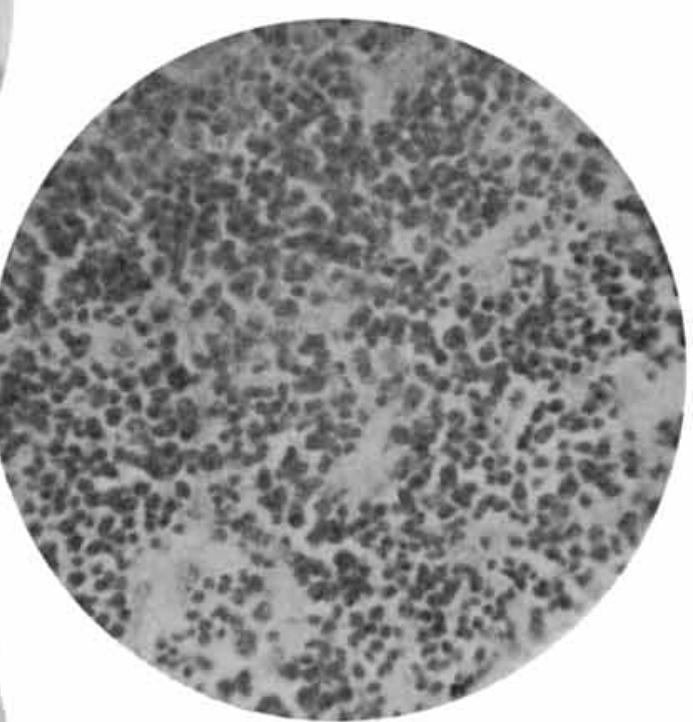

F16. 2.

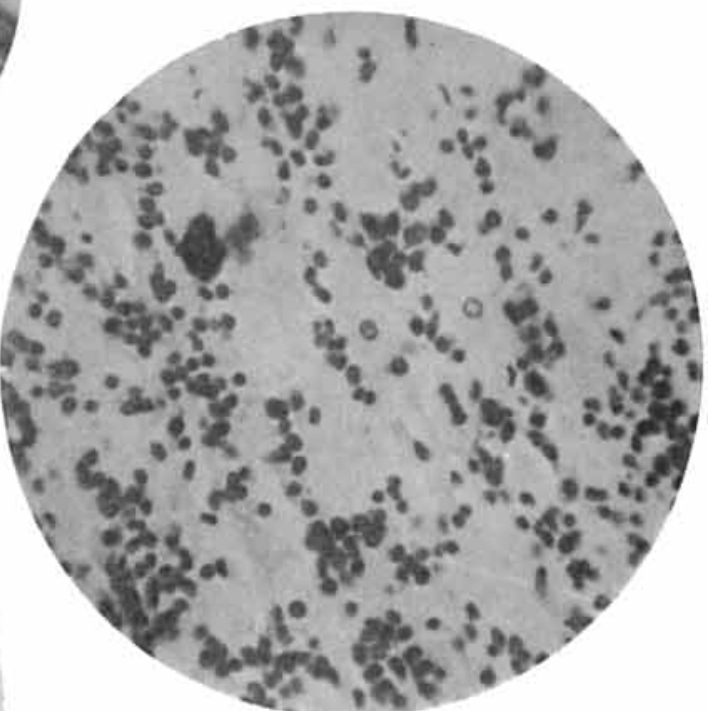

Fic. 4. 


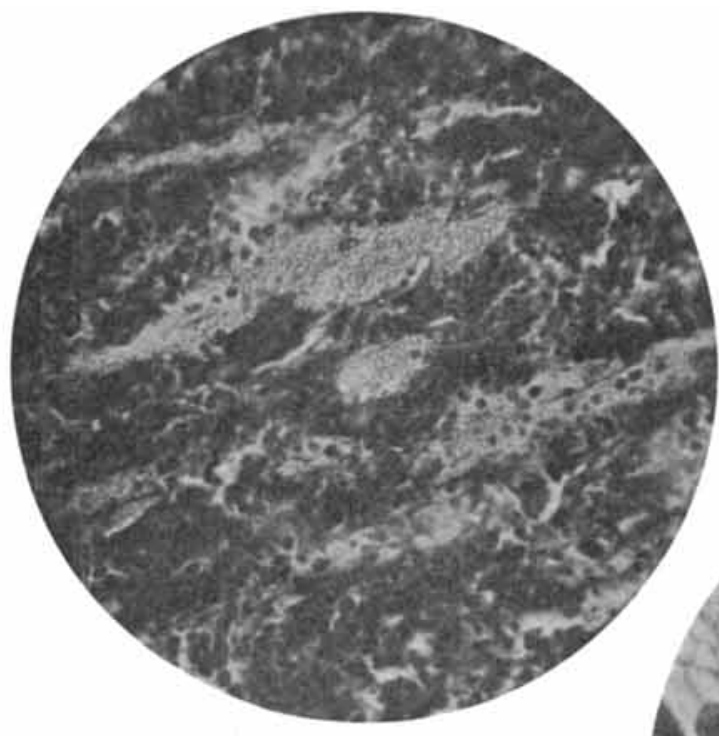

Fic. 6 .
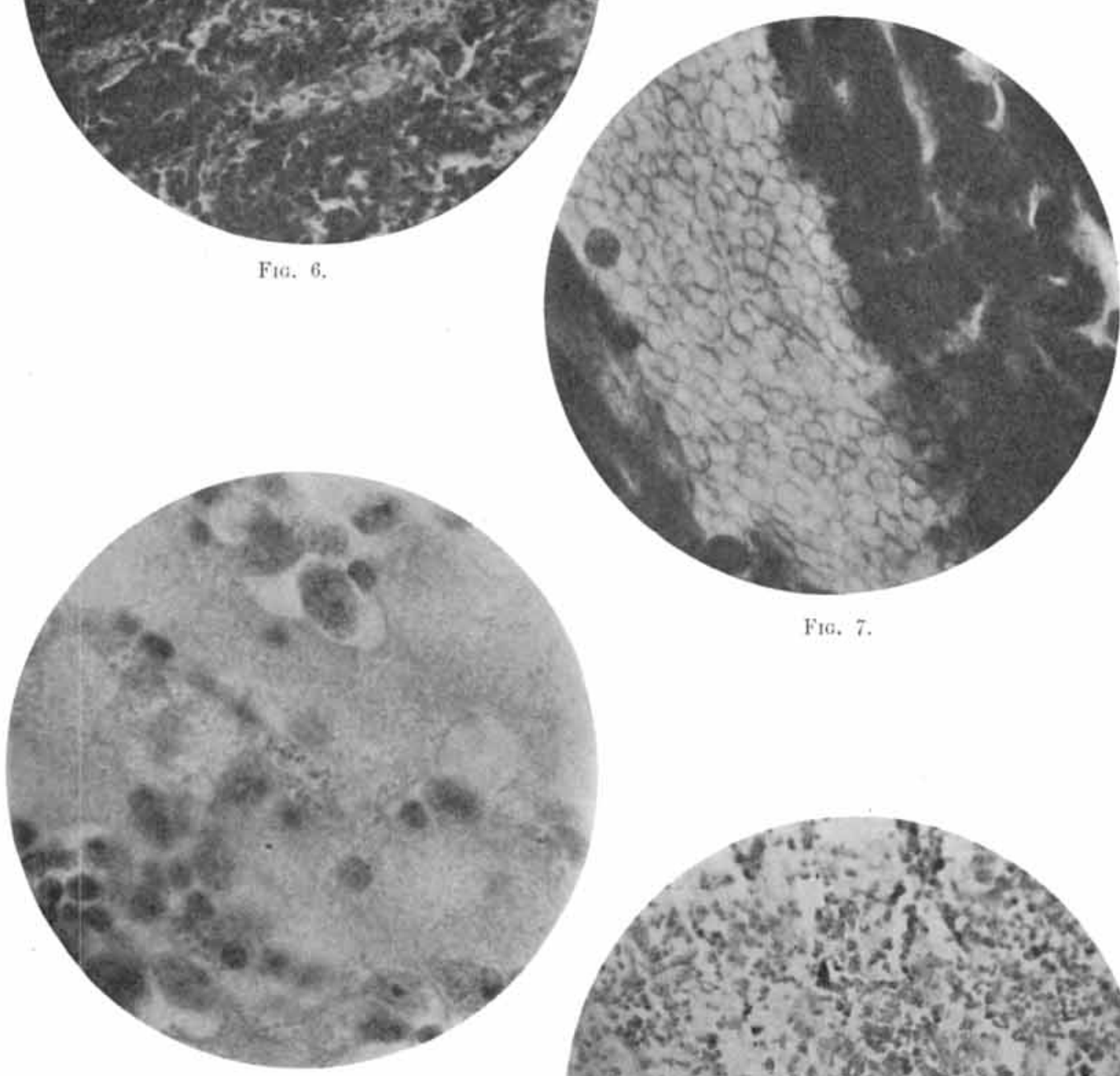

Fic. 7.

Fic. 8.

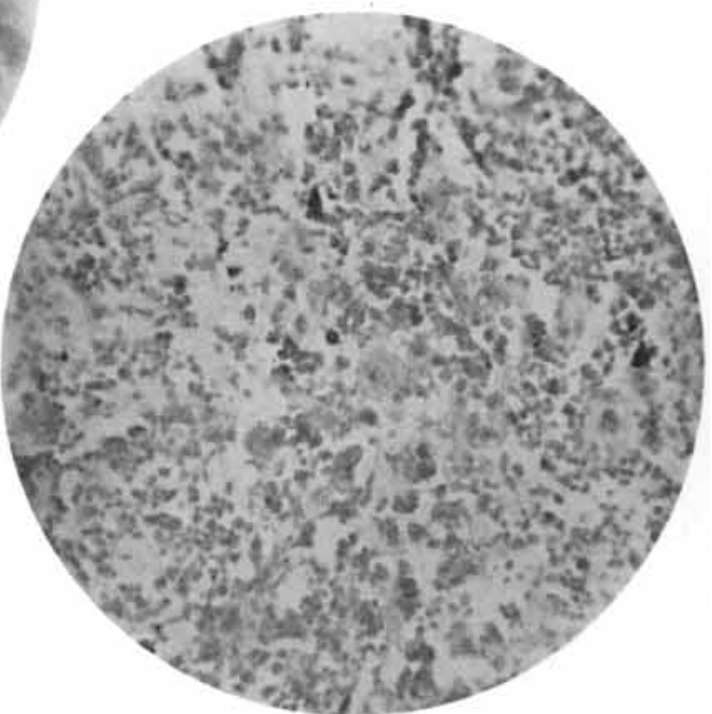

FIc. 9. 
globin fell in fourteen days from $5,880,000$ per c.mm. and 68 per cent. to $3,040,000$ and 36 per cent. respectively; in another, from $6,900,000$ and 52 per cent. to $3,920,000$ and 20 per cent. in nine days ; and in a third, from $6,200,000$ and 55 per cent. to $3,000,000$ and 30 per cent. in eight days. We gave the lead carbonate by the mouth, mixed with the food, and found (possibly, however, owing to differences of absorption) that the animals varied much in their resistance to its action. The adult rabbits died after taking from 13 to 65 grs. - a very wide difference; they all emaciated greatly, losing from one-ninth to one-third of their original weight, and showed great muscular atrophy and weakness. One had symptoms like those of lead encephalopathy, and another had marked contraction of the large intestine at parts.

We are not aware of any examinations of the bone marrow of man in recent cases of lead-poisoning. The only published research bearing on the subject is one by Raimondi $\left({ }^{2}\right)$ on three rabbits, to which he gave lead acetate for a period of two to four months, and found that it induced anæmia, hydræmia, and melanæmia. On examining the bone marrow he found that the fat had disappeared, and that it was in a condition of gelatinous degeneration.

We have examined the bone marrow of the femur in ten rabbits suffering from lead-poisoning, and in all of them it was much altered, but in some very profoundly as compared with others. The accompanying photographs show the changes, which bear a strong resemblance to those which occur in the case of some other poisons.

In Fig. 2 (Plate XIV.) there is almost complete disappearance of the fat cells and a great increase in the number of the marrow cells, the tissue looking much more cellular and denser than the normal. The cells which increase so much in number at this stage are the leucoblasts, those, namely, which give origin to the finely granular polynuclear leucocytes of the blood. The same change is seen under the action of arsenic and many other poisons and toxins, and is connected with an increased supply of leucocytes from the marrow cells to the blood, with the object of absorbing the poison. Some of our specimens showed a slight increase in the number of capillary blood vessels also; but this is often absent, and is quite insignificant when compared with the similar changes which take place in the early stage of arsenic and mercury poisoning. Gelatinous degeneration of the marrow soon occurs, the fat cells atrophying and the connective tissue being converted into a homogeneous substance resembling mucin, but not identical with it. In some of our sections it was perfectly clear and hyaline, in others it had a granular or streaked appearance, probably due to precipitation of albuminous material by the reagents used in hardening the tissues. At the same time, the marrow cells-erythroblasts and leucoblasts alikediminish greatly in number, while the giant cells are sometimes fewer and greatly degenerated, and sometimes little affected. Different degrees of these degenerative changes are shown in Figs. 3, 4, 5 (Plate XIV.), in the last of which very little marrow tissue is left.

\section{Summary.}

1. Chronic lead-poisoning causes marked anæmia. 
2. The bone marrow shows, at first, a marked increase in its leucoblast cells, with disappearance of its fat, and sometimes a very moderate amount of hyperæmia.

3. This is succeeded by gelatinous degeneration with atrophy of the whole marrow tissue.

\section{Mercury.}

Previous observations regarding the action of mercury on the bone marrow of rabbits have been made by Raimondi $\left({ }^{2}\right)$ and by Heilborn $\left({ }^{3}\right)$. The former used corrosive sublimate, and gave to three rabbits, by the mouth, repeated doses of 1 to 20 mgrms. He describes the blood as hydræmic, containing few red corpuscles and an increased number of white-the latter filled with dark pigment; and the marrow as containing much extravasated blood, less fat than usual, and a few nucleated cells. Heilborn also used mercuric chloride, but by subcutaneous injection, and in doses of 5 to $65 \mathrm{mgrms}$. The larger amounts killed at once, or after a few doses; the smaller could be given for two or three weeks. He found the bone marrow extremely hyperæmic, with no increase of its nucleated red cells, and much atrophy of its fat cells. Similar results were obtained in dogs.

As regards the blood, Keyes $\left(^{4}\right)$ found that small doses of mercury increased the number of blood corpuscles in healthy men and in syphilitics, while larger doses diminished it-results which have been confirmed by Lindstroem $\left({ }^{5}\right)$, in syphilis, for both the red cells and hæmoglobin. Schlesinger $\left({ }^{6}\right)$, experimenting on rabbits and dogs with small doses of mercuric chloride ( $\frac{1}{2}$ mgrm.), found a very substantial increase in the red corpuseles and hæmoglobin (as much as 2,000,000 per c.mm. and 30 per cent.), an increase so large as to preclude any possibility of error. In the mercurial cachexia of man and animals there is always marked anæmia.

Our experiments were made on rabbits, with corrosive sublimate and calomel. The former was given subcutaneously in 1-mgrm. dose daily, the latter in 6-corm. doses by the mouth. All of them emaciated very much and died in three or four weeks.

Under corrosive sublimate the changes in the marrow resemble those produced by arsenic $(7)$, but are much more intense. There is probably, with minute doses, a stimulation of the erythroblastic cells as well as of the leucoblastic, but this stage we never saw. With larger doses the first effect is intense hyperæmia with very great increase in the number, size, and fulness of the capillary vessels, accompanied by great atrophy or complete disappearance of the fat cells. At some places the blood vessels occupy nearly the whole field of the microscope, and occasionally the blood has extravasated. These changes are shown in Figs. 6 and 7 (Plate XV.). Gelatinous degeneration begins very soon and advances rapidly, the marrow cells becoming very few in number, changes which are shown under a high power in Fig. 8 (Plate XV.). None of our specimens show an increase either of leucoblast or erythroblast cells, probably because we used too large doses and examined the marrows at too late a stage of the poisoning. With calomel the hyperæmia was not nearly so marked, and the degenerative changes took place more slowly (Plate XV. Fig. 9). Giant cells were usually present in fair number and not degenerated. 


\section{Summary.}

1. We did not observe the increase of red corpuscles and hæmoglobin which has been described by other observers as the result of giving minute doses of mercury. This is probably due to our having used comparatively large doses, under which the animals rapidly emaciated.

2. The first effect observed was a very striking increase in the number and size of the blood vessels of the marrow, accompanied by complete atrophy of its fat cells. Small extravasations of blood were commion.

3. Gelatinous degeneration occurs very early and is extreme.

4. Along with it the cellular elements of the marrow disappear.

5. With calomel the hyperæmia was much less than with mercuric chloride, and the degenerative changes were more gradual and less complete.

\section{Phosphorus.}

The only previous research on the action of phosphorus on the bone marrow is one on rabbits by Roger and Josué ${ }^{8}$ ), who describe two kinds of changes(1) cellular proliferation, as in microbic affections; and (2) lesions of a special character peculiar to phosphorus.

Our observations were conducted on rabbits, which received subcutaneously about $1 \mathrm{mgrm}$., dissolved in oil at each dose. Some of them died after a few doses, others survived from thirty to forty-five doses. Most of them died more or less emaciated, and on section fatty degeneration of the viscera was found. No observations were made on the blood.

The changes found in the marrow depend largely on the length of time the phosphorus had been given. In one, the only marked change was hyperæmia; in others, there existed in addition atrophy of the fat cells, and great increase in the leucoblast marrow cells (Plate XVI. Fig. 10), without gelatinous degeneration. Sooner or later gelatinous degeneration begins, with great decrease in the number of marrow cells (Plate XVI. Fig. 11), the giant cells degenerate, and the connective tissue becomes coarser. The degenerated tissue, instead of being hyaline, is often very granular, and has the appearance of being streaked (Plate XVI. Figs. 12 and 13).

The early changes in the marrow are similar to those seen under the action of arsenic and microbic poisons, and indicate a reaction on the part of the marrow for the purpose of dealing with the poison. As the poisoning becomes more severe and obtains the upper hand, the marrow degenerates rapidly and its cellular structure disappears, just as happens in many other poisonings and cachectic conditions. A few fattily degenerated masses are seen scattered about; this is peculiar to phosphorus.

We found no marked increase in the thickness of the bones. 


\section{Summary.}

1. The changes are essentially similar in kind to those which occur with arsenic, lead, and mercury.

2. There is hyperæmia of the marrow, followed by increase of the leucoblasts and atrophy of the fat cells, and later, by gelatinous degeneration and diminution in the number of cells.

3. A certain amount of fatty degeneration takes place in the marrow as in other viscera, and its connective tissue becomes coarser.

\section{IRON.}

The action of iron on the marrow is of special interest with reference to its hæmatinic effects.

Hofmann $\left({ }^{9}\right)$ states that in anæmia it acts by stimulating directly the blood-forming process in the marrow, and not by merely supplying the iron necessary for the formation of an increased amount of hæmoglobin.

We gave iron to rabbits hypodermically and by the mouth, but found that its action on the marrow was not the same in both cases. For hypodermic administration we employed an albuminate of iron, giving an amount equal to $\frac{1}{2}$ or $1 \mathrm{gr}$. Fe daily for periods of thirty to forty days. The rabbits remained in good health and put on weight, a result very different from what occurs with arsenic, lead, mercury, or phosphorus. On examination the bone marrow was found to present slight changes only. In one case the marrow was normal in many places, but here and there the lencoblast cells were undoubtedly increased in number. In the others there was a certain degree of atrophy of the fat cells, never extreme, but quite recognisable; the blood vessels were sometimes slightly more numerous than normal, and the leucoblastic cells were increased in number. The giant cells were always very numerous, but there was no increase, at least no marked increase, of the erythroblastic cells. These constitute all the changes, and they simply indicate a very mild reaction against a foreign or slightly poisonous body circulating in the blood. All the viscera gave the iron reaction very deeply. In the marrow iron granules were observed in many of the cells, and the endothelium of the blood vessels gare a diffuse staining.

We also gave to several rabbits 5 grs. $(0.4 \mathrm{grm}$.) reduced iron daily in their food, for twenty-three to forty days. The animals remained in good health and condition. The iron was absorbed, as shown by a careful examination of the viscera, after staining with ferrocyanide of potassium and hydrochloric acid, and examining them microscopically. The liver stained deeply, and we found blue granules in the cells, in the intercellular spaces, and in the capillaries. The spleen also stained deeply, except the Malpighian corpuscles; the 
stomach stained very slightly, the small intestine more deeply, and the large intestine very deeply. Traces were found in the Malpighian tufts, and in a few of the tubule cells of the kidney, and in an abdominal lymph gland.

In sections of the bone marrow we found very little iron. $A$ few cells here and there contained blue granules, and the capillary endothelium stained diffusely in some places. Otherwise the bone marrow appeared normal. We could detect no alteration in the amount of fat, in the blood vessels, or in the marrow cells. This seems to prove that iron taken by the mouth is absorbed from the bowel, and is then caught and retained by the spleen and liver, being stored in the latter organ and used as required for making hæmoglobin, the surplus being excreted into the large intestine. Very little of it comes to the marrow, unless required for making hæmoglobin; and hence it does not directly stimulate the marrow to form new red corpuscles, but merely supplies the necessary iron in the form of an organic compound.

\section{Summary.}

1. When iron is given hypodermically to rabbits there is a slight reaction on the part of the marrow, not specific, but such as happens with many other foreign bodies.

2. When iron is given by the mouth no change occurs in the structure of the marrow, and there is no evidence of increased formation of red blood corpuscles.

4. Iron, therefore, promotes formation of red blood corpuscles, simply by supplying the necessary hæmoglobin.

\section{QUININE.}

The acid hydrochloride of quinine was given to rabbits subcutaneously, in varying doses, for considerable periods. We found, however, that it had no effect on the histological structure of the bone marrow.

\section{EXPLANATION OF PLATES XIV.-XVI.}

\section{Plate XIV.}

FIG. 1.-Normal bone marrow of rabbit. ( $\times 350$ diams. $)$

Fra. 2.-Early action of lead on bone mairow: atrophy of fat cells, great increase of leucoblasts. $(\times 250$.

Fias. 3, 4.-Gelatinous degeneration: diminution in number of cellular elements. $(\times 250$.

Frg. 5. - A later stage of same. $(\times 250$.

PLATE XV.

FIG. 6.-Action of mercuric chloride on bone marrow : very great hyperænia, atroplyy of fat cells. $(\times 230)$. 
FIG. 7.-Same. ( $\times 1250$ : shows capillary vessel.)

FIG. 8.-Same, $\times 1250$ : shows gelatinous degeneration, few marrow cells, and atrophy of fat cells.

Fia. 9.-Action of calomel: shows some gelatinous degeneration, atrophy of fat cells, increase of leucoblast cells. $(\times 250$.

Plate XVI.

FIG. 10.-Early action of phosphorus : atrophy of fat cells, commencing gelatinous degeneration, increase of lencoblast cells. $(\times 250$.

FIG. 11.-A later stage of phosphorus action. $(\times 250$.

Frg. 12.-A still later stage: extreme gelatinous degeneration, atrophy of fat cells, and almost complete disappearance of the cellular elements of marrow. $(\times 690)$.

FIG. 13. - A later stage: gelatinous degeneration, and fibrous tissue coarser. $(\times 690$.

\section{REFERENCES.}

1. Malassez. . . . . . Arch. de physiol. norm. et path., Paris, 1877, tome iv. p. 634 .

2. Raimondr. . . . . Ann. univ. di med. e chir., Milano, 1880, vol. celi. p. 52.

3. Heilborn . . . . . . Arch. f. exper. Path. u. Pharmakol., Leipzig, 1878, Bd. viii. S. 361.

4. Keyes. . . . . . . Am. Journ. Med. Sc., Phila., 1876, vol. lxxi. p. 17.

5. Lindstroem . . . . . Presse méd., Paris, 1898.

6. Schlesinger . . . . . Arch. f. exper. Path. u. Pharmakol., Leipzig, 1881, Bd. xiii. S. 317.

7. Stockman and Greig . Journ. Physiol., Cambridge and London, 1898, vol. xxiii. p. 376 .

8. Stockman and Chanteris Journ. Path. and Bacteriol., Edin. and London, 1903, vol. viii. p. 443.

9. Roger and Josué . . . Compt. rend. Soc. de biol., Paris, 1899, p. 436.

10. Hofmann . . . . . . Virchow's Archiv, 1900, Bd. clx. S. 235. 


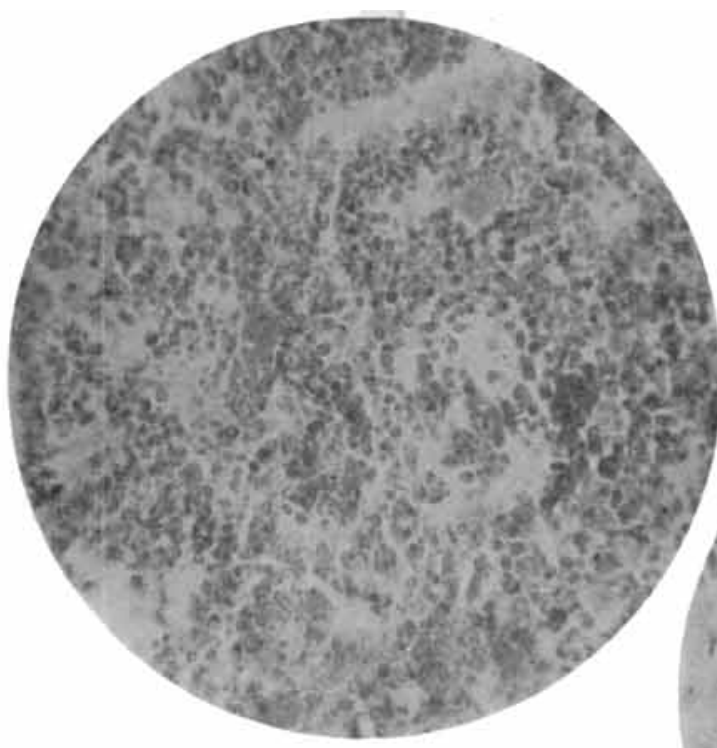

Fic. 10.

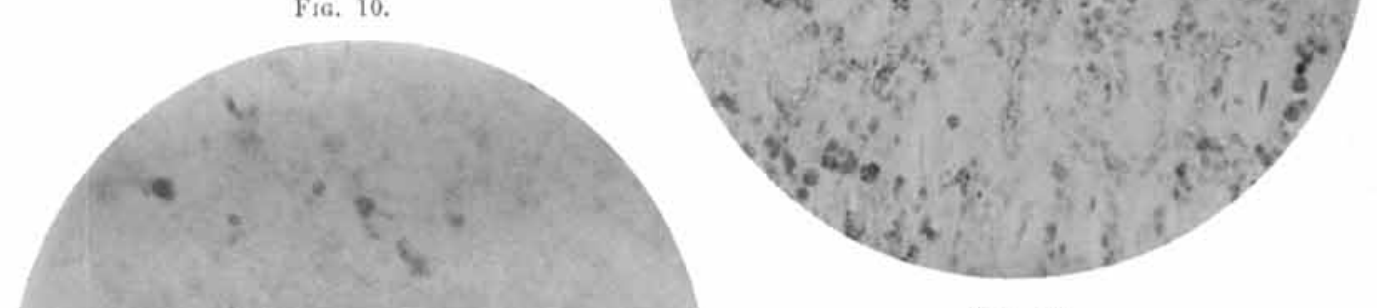

F16. 11.
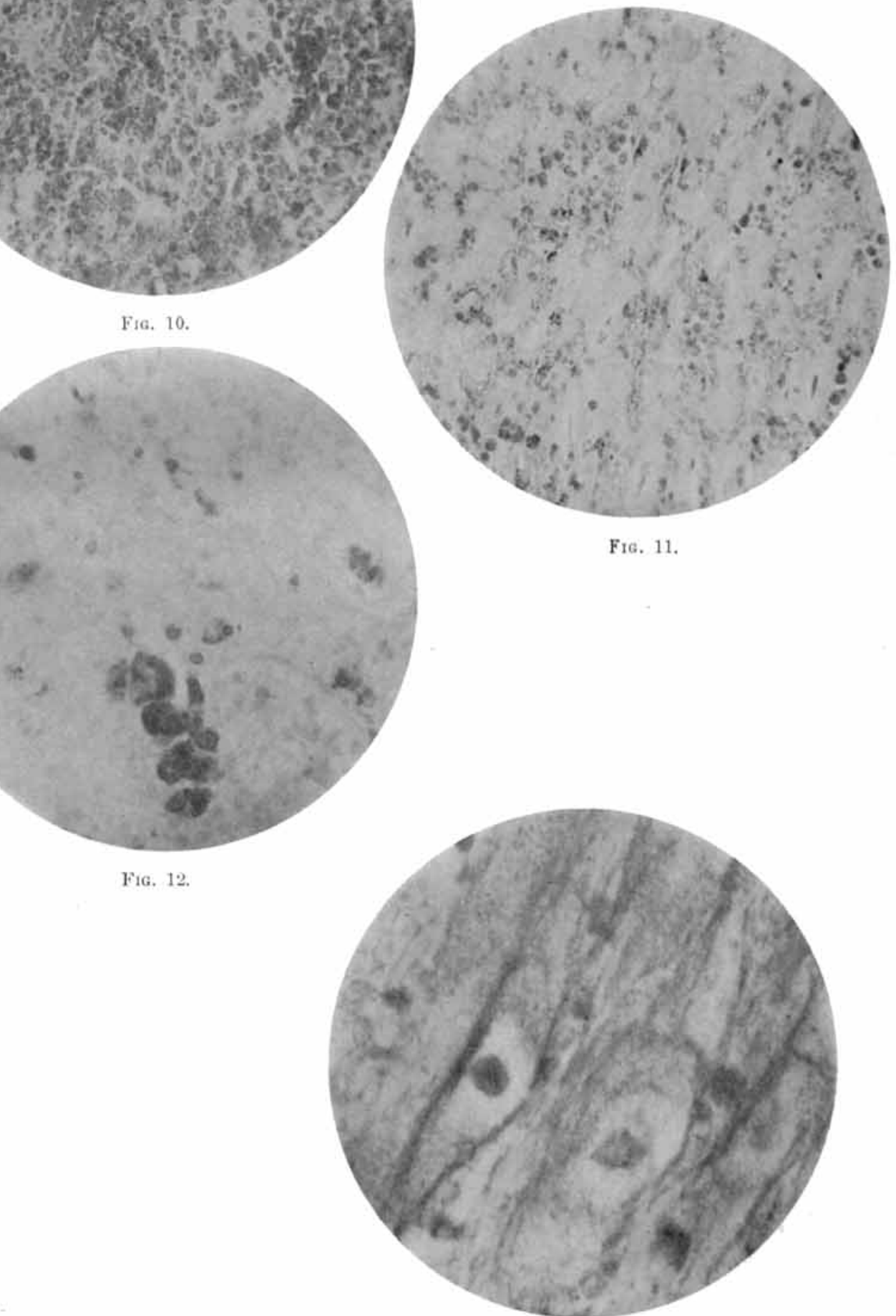

Fig. 13. 